\title{
Sensitization to the Effects of Tumor Necrosis Factor- $\alpha$ : Neuroendocrine, Central Monoamine, and Behavioral Variations
}

\author{
Shawn Hayley, ${ }^{1}$ Karen Brebner, ${ }^{1}$ Susan Lacosta, ${ }^{1}$ Zul Merali, ${ }^{2}$ and Hymie Anisman ${ }^{1}$ \\ 1/nstitute of Neuroscience, Carleton University, Ottawa, Ontario K1S 5B6, Canada, and 2School of Psychology and \\ Department of Cellular and Molecular Medicine, University of Ottawa, Ottawa, Ontario K1N 6N5, Canada
}

Consistent with the proposition that cytokines act as immunotransmitters between the immune system and the brain, systemic administration of the proinflammatory cytokine tumor necrosis factor- $\alpha$ (TNF- $\alpha$; 1.0-4.0 $\mu \mathrm{g}$ ) induced mild illness in CD-1 mice, increased plasma corticosterone concentrations, and altered central norepinephrine, dopamine, and serotonin turnover. The actions of TNF- $\alpha$ were subject to a timedependent sensitization effect. After reexposure to a subeffective dose of the cytokine $(1.0 \mu \mathrm{g}) 14-28 \mathrm{~d}$ after initial treatment, marked illness was evident (reduced consumption of a palatable substance and diminished activity and social exploration), coupled with an elevation of plasma corticosterone levels. In contrast, cytokine reexposure 1-7 d after initial treatment did not elicit illness, and at the $1 \mathrm{~d}$ interval the corticosterone response to the cytokine was reduced. The increase of norepinephrine release within the paraventricular nucleus of the hypothalamus, as reflected by elevated accumulation of 3-methoxy-4-hydroxyphenylglycol, was augmented at the longer reexposure intervals. In contrast, within the central amygdala and the prefrontal cortex TNF- $\alpha$ reexposure at the $1 \mathrm{~d}$ interval was associated with a pronounced sensitization-like effect, which was not apparent at longer intervals. Evidently, systemic TNF- $\alpha$ proactively influences the response to subsequent treatment; however, the nature of the effects (i.e., the behavioral, neuroendocrine, and central transmitter alterations) vary over time after initial cytokine treatment. It is suggested that the sensitization may have important repercussions with respect to cognitive effects of TNF- $\alpha$ and may also be relevant to analyses of the neuroprotective or neurodestructive actions of cytokines.

Key words: tumor necrosis factor- $\alpha$; cytokine; sensitization; desensitization; corticosterone; norepinephrine; dopamine; serotonin; sickness behavior
Multidirectional communication exists among the immune, autonomic, hormonal, and central nervous systems (Blalock, 1994; Hopkins and Rothwell, 1995; Maier and Watkins, 1998). It has been suggested, in this respect, that the proinflammatory cytokines interleukin- $1 \beta$ (IL-1 $\beta$ ), IL-6, and tumor necrosis factor- $\alpha$ (TNF- $\alpha$ ) may serve in a signaling capacity between the immune system and the CNS (Dunn, 1992; Hopkins and Rothwell, 1995). These cytokines could affect central processes directly, or they may do so indirectly through stimulation of vagal afferents (Bluthe et al., 1996; Maier and Watkins, 1998). Moreover, it has been suggested that variations of peripheral cytokine activity may be interpreted by the brain as a stressor (Dunn et al., 1989; Dunn, 1990; Anisman and Merali, 1999).

In addition to hormonal changes (e.g., plasma corticosterone or $\mathrm{ACTH}$ ), cytokines may provoke variations of central neurotransmitter activity (Dunn and Welch, 1991; Linthorst et al., 1995), thus eliciting behavioral alterations (Linthorst et al., 1995; Lacosta et al., 1998). Interestingly, cytokines may not only have immediate effects but may also result in the sensitization of neuroendocrine and neurotransmitter processes, such that the subsequent response to cytokine or stressor challenge is enhanced. For instance, IL-1 $\beta$ provoked increased colocalization of

\footnotetext{
Received Jan. 21, 1999; revised April 8, 1999; accepted April 20, 1999.

This research was supported by Grant MT-13124 from the Medical Research Council of Canada. The assistance of Jerzy Kulczycki is greatly appreciated.

Correspondence should be addressed to Hymie Anisman, Life Science Research Building, Carleton University, Ottawa, Ontario K1S 5B6, Canada.

Copyright (C) 1999 Society for Neuroscience $0270-6474 / 99 / 195654-12 \$ 05.00 / 0$
}

arginine vasopressin (AVP) and corticotropin-releasing hormone $(\mathrm{CRH})$ in $\mathrm{CRH}$ terminals within the external zone of the median eminence (Schmidt et al., 1995, 1996; Tilders and Schmidt, 1998). Because AVP and CRH synergistically provoke pituitary ACTH release, such a process may account for some of the protracted effects of cytokine exposure (Tilders and Schmidt, 1998) and may contribute to pathological states associated with stressor or cytokine challenges (Ravindran et al., 1997).

In addition to the hypothalamic-pituitary-adrenal (HPA) alterations, IL- $1 \beta$ influenced monoamine activity at several extrahypothalamic sites (Linthorst et al., 1995; Merali et al., 1997; Lacosta et al., 1998; Song et al., 1999). As well, IL-1 $\beta$ and stressors synergistically influenced central monoamine activity (Song et al., 1999). In contrast to the attention devoted to the effects of IL-1 $\beta$, a relative paucity of information exists concerning the immediate and proactive central effects of TNF- $\alpha$. This is surprising because this cytokine has been implicated in various CNS processes and pathologies (e.g., neurodegenerative disorders, sepsis, head trauma, and cerebral ischemia) (Giulian and Robertson, 1990; Buttini et al., 1994; Sato et al., 1997).

It was of interest to establish the immediate and proactive effects of systemic TNF- $\alpha$ treatment. In this respect, the present investigation determined (1) the immediate effects of TNF- $\alpha$ administration on an index of sickness behavior (reduced locomotion and social interaction and consumption of a highly palatable food source), plasma corticosterone, as well as central monoamine levels and turnover at hypothalamic and extrahypothalamic sites, (2) whether administration of this cytokine proac- 
tively influenced neurochemical and behavioral processes after subsequent reexposure to subeffective cytokine doses, and (3) whether such a sensitization was dependent on the time between the initial TNF- $\alpha$ treatment and subsequent reexposure.

\section{MATERIALS AND METHODS}

Male CD-1 mice, 8-10 weeks of age, were obtained from Charles River (Laprairie, Quebec, Canada). Mice were housed in groups of four in standard propylene cages and given at least 2 weeks to acclimate to the laboratory. Animals were maintained on a $12 \mathrm{hr}$ light/dark cycle with lights on at 8 A.M., room temperature was kept at $21^{\circ} \mathrm{C}$, and mice were permitted an ad libitum diet of Ralston Purina (St. Louis, MO) mouse chow. All experimental procedures were approved by the Carleton University Committee for Animal Care and met the guidelines set out by the Canadian Council on Animal Care.

Procedure. To minimize the contribution of diurnal variations associated with neurotransmitter or neuroendocrine processes, all experimental procedures were conducted between 8 A.M. and 12 P.M. CD-1 mice were used in this experiment because central amine and neuroendocrine effects of stressors have been characterized in this outbred strain, as have the immediate behavioral and neurochemical responses to IL-1 $\beta$ and TNF- $\alpha$ (Shanks et al., 1991; Brebner et al., 1998; Lacosta et al., 1998).

Mice ( $n=20$ per group) received an initial intraperitoneal injection with either sterile nonpyrogenic saline $(0.9 \%)$ or $4.0 \mu \mathrm{g}$ of TNF- $\alpha$ in a volume of $0.4 \mathrm{ml}$ of sterile saline, followed by a second injection of $1.0 \mu \mathrm{g}$ of the cytokine. The latter treatment was administered $1,7,14$, or $28 \mathrm{~d}$ after the initial TNF- $\alpha$ treatment. Three additional groups of mice were included; one group received saline on two occasions $14 \mathrm{~d}$ apart; a second received saline followed $14 \mathrm{~d}$ later by the low dose of TNF- $\alpha(1.0 \mu \mathrm{g})$; and the third group received TNF- $\alpha(4.0 \mu \mathrm{g})$ followed $14 \mathrm{~d}$ later by saline. Human recombinant TNF- $\alpha$ (specific activity, $1.1 \times 10^{5} \mathrm{U} / \mu \mathrm{g}$ ) was obtained from R \& D Systems (Minneapolis, MN) in lyophilized form, subsequently dissolved in sterile PBS, and stored in $20 \mu \mathrm{l}$ aliquots at $-80^{\circ} \mathrm{C}$. At $1.0 \mathrm{hr}$ after the second injection mice were decapitated, and brains collected, frozen in isopentane, and then stored at $-80^{\circ} \mathrm{C}$ until later sectioning and removal of nuclei for analysis of central biogenic amines and metabolites. Trunk blood was centrifuged, and the supernatant was stored at $-80^{\circ} \mathrm{C}$ in tubes containing $10 \mu \mathrm{l}$ of EDTA for the determination of plasma corticosterone levels. The $1.0 \mathrm{hr}$ interval between TNF- $\alpha$ administration and subsequent decapitation was chosen on the basis of an earlier study showing that behavioral and glucocorticoid variations were marked at this time (Brebner et al., 1998).

In addition to the neurochemical alterations, this experiment also assessed whether behavioral outputs would be associated with reexposure to cytokine treatment and whether such behavioral effects would appear sooner in mice that received the reexposure treatment. Behavioral measures were recorded from half of the mice (i.e., in one of two replications of the study) during the reexposure phase of the study $(n=10$ per group). After intraperitoneal injection mice were returned to their home cages, and their behavior, including social interaction with noninjected cage mates, was recorded up to the time at which the brain and blood were collected. Commencing $15 \mathrm{~min}$ after the intraperitoneal injection and at the three successive $15 \mathrm{~min}$ intervals, the following behaviors were rated, for a $10 \mathrm{sec}$ period, on four-point scales: locomotor activity $(1=$ no movement; 2 = slow, lethargic movements; 3 = normal locomotion; and $4=$ hyperactive, continuous movement); social interaction $(1=$ animal huddling with cage mates; 2 = occasional interaction with cage mates; $3=$ predominately staying away from cage mates; and $4=$ isolated from cage mates, typically in corner); overall sickness $(1=$ normal looking; 2 = slightly lethargic, slow movement, slightly ruffled fur, and eyes slightly drooping; 3 = lethargic, fur ragged, eyes drooping, and breathing altered; and 4 = very sick appearance, ptosis, ragged fur, curled body posture, difficulty breathing, and general nonresponsiveness). This procedure was found to provide $>90 \%$ agreement between raters blind to the treatment mice received.

To obtain a further index of sickness behavior, an additional experiment, involving naïve CD-1 mice, assessed the effects of TNF- $\alpha$ on consumption of a palatable solution. Mice that received ad libitum food were offered free access to chocolate milk (Sealtest; Ault Foods, Etobicoke, Ontario, Canada; $1 \%$ partly skimmed) for $1 \mathrm{hr}$ each day during the light phase (commencing at 10 A.M.). Bottles were weighed at the beginning and end of the hour to determine total consumption (weights were converted to volume). After the establishment of a steady rate of drinking (3 consecutive days during which consumption varied by
$<10 \%$ ), mice received an acute intraperitoneal injection of either TNF- $\alpha$ $(1.0,2.0$, or $4.0 \mu \mathrm{g})$ or saline and were then returned to their home cages. Two weeks later, mice of each group ( $n=10$ per group) were subdivided and treated with either saline or the lowest dose $(1.0 \mu \mathrm{g})$ of TNF- $\alpha$. Commencing $1 \mathrm{hr}$ later, corresponding to the time of the neurochemical determinations in the preceding study, chocolate milk was presented to the mice individually, and consumption was recorded over a $1 \mathrm{hr}$ period.

Brain dissection. Frozen brains were placed on a stainless steel dissecting block with slots (spaced $\sim 100 \mu \mathrm{m}$ apart) that served as guides for razor blades, which were used to provide a series of coronal brain sections. The dissection of the brain was conducted in a cold chamber, with the brain resting on a stage containing dry ice. Brain sections were mounted on glass slides and placed on a Petri dish filled with powdered dry ice, which served as a cold stage. Using the mouse brain atlas of Franklin and Paxinos (1997), brain nuclei were removed by micropunch using hollow 16 or 20 gauge needles with a beveled tip. Tissue was taken bilaterally from the paraventricular nucleus of the hypothalamus (PVN), locus coeruleus, dorsal hippocampus, central amygdala, and medial prefrontal cortex and then stored at $-80^{\circ} \mathrm{C}$ until processed using HPLC.

HPLC procedure for analysis of brain amine and metabolite levels. Levels of dopamine (DA), NE, and 5-HT and their respective metabolites 3-methoxy-4-hydroxyphenylglycol (MHPG), 3,4-dihydroxyphenylacetic acid (DOPAC), and 5-hydroxyindole acetic acid (5-HIAA) were determined by HPLC using a modification of the method of Seegal et al. (1986). Tissue punches were sonicated in a homogenizing solution, which comprised $14.17 \mathrm{gm}$ of monochloroacetic acid, $0.0186 \mathrm{gm}$ of EDTA, 5.0 $\mathrm{ml}$ of methanol and $500 \mathrm{ml}$ of $\mathrm{H}_{2} \mathrm{O}$. After centrifugation, the supernatants were used for the HPLC analysis. Using a Waters Associates (Milford, MA) M-6000 pump, guard column, radial compression column $(5 \mathrm{~m}, \mathrm{C} 18$ reverse phase, $8 \mathrm{~mm} \times 10 \mathrm{~cm})$, and three cell coulometric electrochemical detector (ESA model 5100A), $20 \mu \mathrm{l}$ of the supernatant was passed through the system at a flow rate of $1.5 \mathrm{ml} / \mathrm{min}(1400-1600$ psi). The mobile phase used for the separation was a modification of that used by Chiueh et al. (1983); each liter consisted of $1.3 \mathrm{gm}$ of heptane sulfonic acid, $0.1 \mathrm{gm}$ of disodium EDTA, $6.5 \mathrm{ml}$ of triethylamine, and 35 $\mathrm{ml}$ of acetonitrile. The mobile phase was then filtered $(0.22 \mathrm{~mm}$ filter paper) and degassed, after which the $\mathrm{pH}$ was adjusted to 2.5 with phosphoric acid. The area and height of the peaks was determined using a Hewlett-Packard (Palo Alto, CA) integrator. The protein content of each sample was determined using bicinchoninic acid with a protein analysis kit (Pierce Scientific, Brockville, Ontario, Canada) and a spectrophotometer (PC800 colorimeter; Brinkmann Instruments, Westbury, NY). The lower limit of detection for the monoamines and metabolites was $\sim 5.0 \mathrm{pg}$.

Plasma corticosterone assay. Plasma corticosterone levels were determined (in duplicate) using a commercially available radioimmunoassay (RIA) kit (ICN Biomedicals, Costa Mesa, CA). To avoid interassay variability, all samples within an experiment were assayed within a single run. The intra-assay variability was $<6 \%$.

Statistical analyses. Consumption of chocolate milk was analyzed in two stages. Specifically, the initial response to TNF- $\alpha$, as a function of the dosage (saline, 1.0, 2.0, or $4.0 \mu \mathrm{g}$ ) was evaluated as a repeated measures ANOVA comparing baseline consumption (the data from the $3 \mathrm{~d}$ before reexposure were averaged to provide the baseline score) and that observed $1 \mathrm{hr}$ after TNF- $\alpha$. The second phase assessed the effect of reexposure to TNF- $\alpha$. To this end, the consumption before, at reexposure, and $24 \mathrm{hr}$ after reexposure was analyzed as a repeated measures ANOVA as a function of the initial and reexposure TNF- $\alpha$ treatment that mice received.

The sickness behaviors animals displayed (overall appearance, locomotion, and social interaction) and the plasma corticosterone concentrations were analyzed by single-factor ANOVAs, followed by NewmanKeuls multiple comparisons $(\alpha=0.05)$ of the significant main effects. Owing to the multiplicity of analyses required for the neurochemical alterations across brain regions, multivariate ANOVA (MANOVA) was called for. However, given the number of brain regions and transmitters and metabolites, relative to the number of mice tested, a single MANOVA was not possible. Accordingly, independent MANOVAs were conducted for those regions in which NE, DA, 5-HT, and their metabolites were assessed. Where significant effects were detected, univariate analyses were conducted, followed by Newman-Keuls multiple comparisons of the means of significant effects. Because only NE and MHPG were analyzed within the locus coeruleus, these data were analyzed by ANOVA, followed by multiple comparisons of the treatment means. It might be noted, as well, that separate analyses were also 


$\begin{aligned} & \text { Table 1. Consumption (mean } \pm \text { SEM) of a palatable liquid after acute } \\
& \text { TNF- } \alpha\end{aligned}$
\begin{tabular}{lll} 
TNF- $\alpha(\mu \mathrm{g})$ & Baseline $(\mathrm{ml})$ & Test day $(\mathrm{ml})$ \\
\hline Saline & $3.48 \pm 0.23$ & $3.95 \pm 0.27$ \\
1.0 & $3.83 \pm 0.24$ & $3.38 \pm 0.22$ \\
2.0 & $3.55 \pm 0.18$ & $2.60 \pm 0.23^{*}$ \\
4.0 & $3.42 \pm 0.17$ & $2.18 \pm 0.22^{*}$ \\
\hline${ }^{*}<<0.05$ relative to baseline and saline treatmo
\end{tabular}

${ }^{*} p<0.05$ relative to baseline and saline treatment.

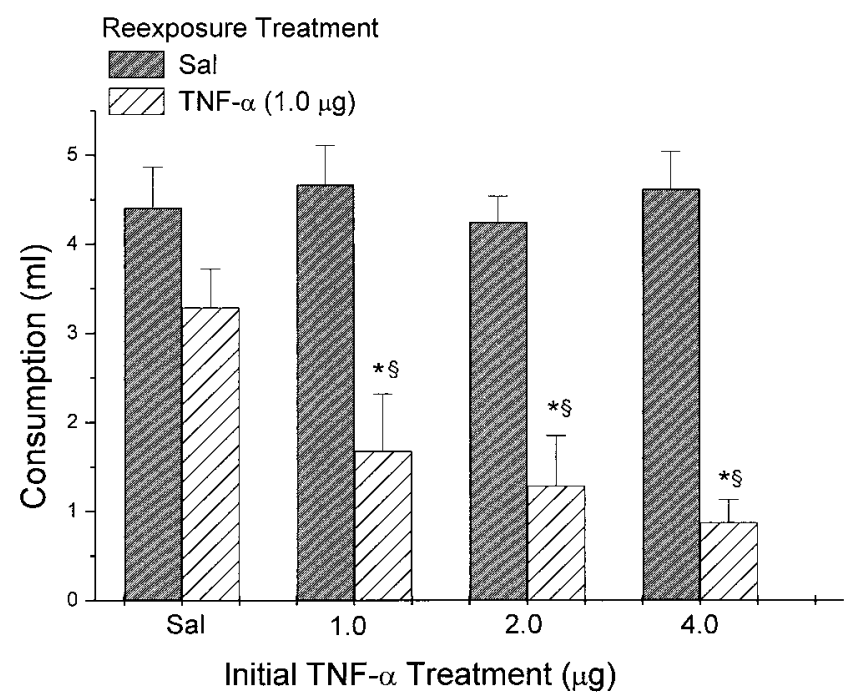

Figure 1. Mean \pm SEM consumption of chocolate milk among mice that received either saline or TNF- $\alpha(1.0,2.0$, or $4.0 \mu \mathrm{g})$ followed 2 weeks later by reexposure to either saline or the $1.0 \mu \mathrm{g}$ dose of the cytokine. The consumption of chocolate milk after first exposure to TNF- $\alpha$ in these same animals is shown in Table $1 .{ }^{*} p<0.05$ relative to saline-treated mice; ${ }_{p} p<0.05$ relative to mice that received acute TNF- $\alpha$ injection.

performed where (1) the data of the four groups that received TNF- $\alpha$ on two occasions (at different reexposure intervals) were compared by single-factor ANOVAs and (2) the groups that received either saline on two occasions or only a single TNF- $\alpha$ injection (either on the initial injection day or the reexposure day) were compared by ANOVA. Dunnett's tests were used to compare the data for animals reexposed to TNF- $\alpha$ with those that received saline or that received only a single TNF- $\alpha$ treatment. Because these analyses yielded the same effects as did the simpler univariate analyses that included all of the groups, only the results of the latter analyses are presented.

\section{RESULTS}

\section{Behavioral changes associated with TNF- $\alpha$ exposure}

Consumption of chocolate milk varied as a function of the interaction between TNF- $\alpha$ treatment and the time of testing $\left(F_{(3,76)}=17.96 ; p<0.01\right)$. As seen in Table 1 and confirmed by Newman-Keuls multiple comparisons, at baseline the groups displayed comparable levels of chocolate milk consumption. However, a dose-dependent reduction of consumption was evident $1 \mathrm{hr}$ after TNF- $\alpha$ administration, such that the 2.0 and $4.0 \mu \mathrm{g}$ groups displayed lower levels of consumption than did salinetreated animals, as well as consumption levels below that observed at baseline.

As seen in Figure 1, relative to mice that received only a single administration of TNF- $\alpha(1.0 \mu \mathrm{g})$, reexposure to the cytokine induced much greater variations with respect to the consumption of chocolate milk. The ANOVA indeed revealed a significant initial TNF- $\alpha \times$ reexposure TNF- $\alpha$ treatment interaction $\left(F_{(3,72)}=2.97 ; p<0.05\right)$. The multiple comparisons indicated that in the absence of previous TNF- $\alpha$ exposure, the $1.0 \mu \mathrm{g}$ treatment provoked a nonsignificant decline of chocolate milk consumption $(0.10<p<0.05)$. However, among mice that had received TNF- $\alpha$ treatment 2 weeks earlier, irrespective of the dosage, reexposure to TNF- $\alpha(1.0 \mu \mathrm{g})$ markedly reduced chocolate milk consumption. Clearly, TNF- $\alpha$ exerted a sensitization effect, such that the behavioral consequences of the cytokine were greatly increased with reexposure 2 weeks after initial treatment. Within $24 \mathrm{hr}$ of TNF- $\alpha$ administration, consumption scores had returned to baseline values irrespective of the treatment mice received.

The general sickness profile of the mice was also altered after reexposure to the cytokine, and this effect was also dependent on the time between the initial and reexposure treatments (Table 2). In particular, the overall appearance, locomotor activity, and social interaction varied as a function of the time between TNF- $\alpha$ treatments $\left(F_{(6,38)}=21.64,10.57\right.$, and 6.76, respectively; $p<$ 0.01). The Newman-Keuls multiple comparisons confirmed that a single administration of the cytokine did not influence the three indices of illness. Likewise, a second injection of the cytokine 1 or $7 \mathrm{~d}$ after initial administration of TNF- $\alpha$ had little effect on these behavioral indices. However, those animals that received the second injection of the cytokine 14 or $28 \mathrm{~d}$ after the initial treatment displayed greater illness, reduced motor activity, and diminished social exploration relative to mice that received only a single TNF- $\alpha$ treatment.

\section{Corticosterone}

Levels of plasma corticosterone, shown in Figure 2, were significantly influenced by TNF- $\alpha\left(F_{(6,118)}=22.60 ; p<0.01\right)$. The multiple comparisons indicated that acute administration of 1.0 $\mu \mathrm{g}$ of the cytokine increased plasma corticosterone levels appreciably, whereas a $4.0 \mu \mathrm{g}$ dose administered 2 weeks earlier was without effect. As in the case of the behavioral changes, the effects of the reexposure treatment varied as a function of the interval between initial TNF- $\alpha$ administration and subsequent reexposure to the cytokine. Specifically, when the second administration occurred $1 \mathrm{~d}$ after the initial treatment, levels of corticosterone were significantly reduced relative to that seen after acute TNF- $\alpha$ treatment. As the interval between the treatments was lengthened, the effects of the reexposure became progressively greater; at 7 and $14 \mathrm{~d}$ after initial treatment, reexposure to the cytokine yielded corticosterone levels comparable with that of acutely treated mice, whereas at $28 \mathrm{~d}$ TNF- $\alpha$ reexposure provoked corticosterone levels significantly greater than those seen after a single TNF- $\alpha$ injection.

\section{Monoamine variations}

In general, TNF- $\alpha$ influenced central monoamine activity in a region-specific manner. It appeared, as well, that at least some of the effects of the cytokine were subject to a sensitization effect, which was dependent on the time between the two TNF- $\alpha$ treatments. The MANOVAs indicated that neurochemical and metabolite levels within the PVN, hippocampus, prefrontal cortex (PFC), and central amygdala varied as a function of the interaction between the neurochemical substrate and the treatment mice received: Pillais $=0.55, F_{(30,515)}=1.75 ; p<0.01 ;$ Pillais $=0.31$, $F_{(18,306)}=1.91 ; p=0.014$; Pillais $=0.60, F_{(30,515)}=2.35 ; p<$ 0.01 ; Pillais $=0.67, F_{(30,515)}=2.36 ; p<0.01$, respectively. 
Table 2. Behavioral scores after initial $(4.0 \mu \mathrm{g})$ or $\mathrm{TNF}-\alpha$ reexposure $(1.0 \mu \mathrm{g})$

\begin{tabular}{llll} 
& Sickness profile & Motor activity & Social interaction \\
\hline Sal/sal & $1.00 \pm 0$ & $3.00 \pm 0$ & $1.75 \pm 0.25$ \\
Sal/TNF & $1.14 \pm 0.38$ & $2.67 \pm 0.20$ & $1.83 \pm 0.31$ \\
TNF/sal & $1.29 \pm 0.76$ & $2.86 \pm 0.14$ & $1.67 \pm 0.33$ \\
TNF/TNF (1 d) & $1.80 \pm 0.20^{*}$ & $2.00 \pm 0 *$ & $1.40 \pm 0.40$ \\
TNF/TNF (7 d) & $1.67 \pm 0.33$ & $2.00 \pm 0.31^{*}$ & $1.67 \pm 0.33$ \\
TNF/TNF (14 d) & $2.83 \pm 0.17^{* * * *}$ & $1.67 \pm 0.21^{*, * *}$ & $2.83 \pm 0.40^{*, * *}$ \\
TNF/TNF (28 d) & $3.57 \pm 0.20^{*, * *}$ & $1.00 \pm 0 *, *$ & $3.71 \pm 0.29^{*}, * *$ \\
\hline
\end{tabular}

${ }^{*} p<0.05$ relative to saline/saline $(\mathrm{Sal} / \mathrm{sal})$.

$* * p<0.05$ relative to $\mathrm{Sal} / \mathrm{TNF}$.

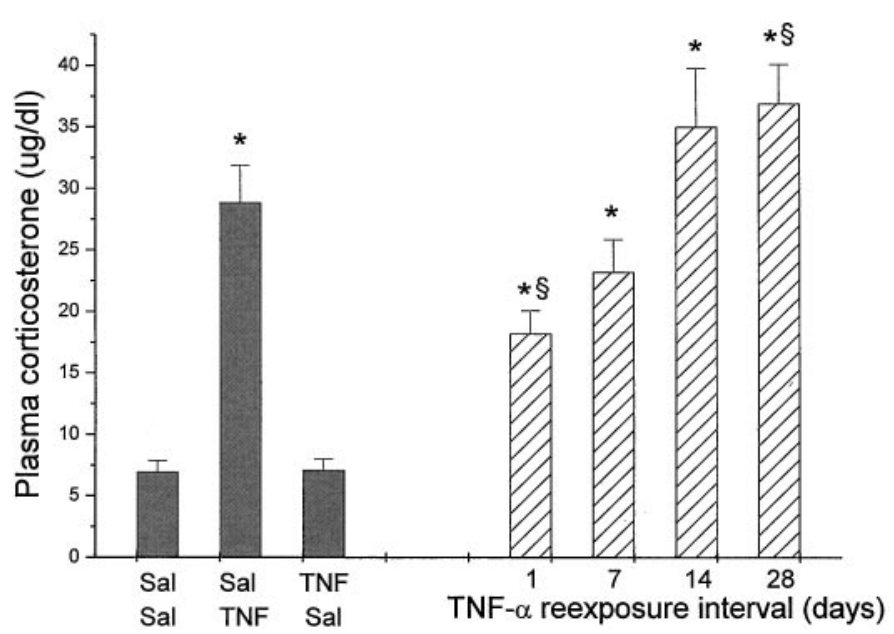

Figure 2. Plasma corticosterone levels (mean \pm SEM) among mice exposed to various TNF- $\alpha$ regimens. All mice received two intraperitoneal injections; the three groups to the left (solid bars) received saline only, saline followed 2 weeks later by the low dose of TNF- $\alpha(1.0 \mu \mathrm{g})$, or a high dose of TNF- $\alpha(4.0 \mu \mathrm{g})$ followed 2 weeks later by saline treatment. The four groups on the right (hatched bars) received two injections of TNF- $\alpha$ : an initial $4.0 \mu \mathrm{g}$ dose followed by a second $1.0 \mu \mathrm{g}$ dose $1,7,14$, or 28 d later. ${ }^{*} p<0.05$ relative to saline treated mice; ${ }^{{ }^{s}} p<0.05$ relative to mice that received acute TNF- $\alpha$ injection.

Univariate analyses revealed that within the PVN, MHPG levels varied as a function of the treatment mice received $\left(F_{(6,126)}=2.87 ; p=0.01\right)$. Relative to saline-treated animals, a single injection of TNF- $\alpha(1.0 \mu \mathrm{g})$ increased the accumulation of MHPG. Among mice reexposed to TNF- $\alpha 1$ or $7 \mathrm{~d}$ after the initial treatment the increase was less marked, whereas at the 14 and $28 \mathrm{~d}$ intervals the MHPG increase was somewhat greater, significantly exceeding that of saline-treated mice. However, in neither case did the MHPG level exceed that of mice that received only a single TNF- $\alpha$ treatment. Unlike the MHPG accumulation, the levels of $\mathrm{NE}$ did not differ dramatically across groups, and none of the TNF- $\alpha$ treatments yielded NE levels that differed from those of saline-treated mice (Fig. 3). A separate ANOVA was conducted of the MHPG/NE ratio within the PVN to ascertain whether the reexposure treatment influenced NE turnover using this particular index. This analysis yielded a significant effect of the treatment $\left(F_{(6,123)}=3.16 ; p<0.01\right)$, and multiple comparisons confirmed that relative to saline-treated mice (MHPG/NE ratio, $0.17 \pm 0.01$ ) acute administration of TNF- $\alpha$ significantly enhanced NE turnover (MHPG/NE ratio, $0.30 \pm 0.04)$. Interestingly, among mice reexposed to the cytokine after a $1 \mathrm{~d}$ interval the $\mathrm{NE}$ turnover was reduced relative to that seen after acute TNF- $\alpha$ treatment (MHPG/NE ratio, $0.21 \pm$ $0.02)$, whereas reexposure to the cytokine after $28 \mathrm{~d}$ resulted in an elevation of the amine turnover $(\mathrm{MHPG} / \mathrm{NE}$ ratio, $0.38 \pm 0.06)$ relative to saline-treated mice or mice that were reexposed to the cytokine after a $1 \mathrm{~d}$ interval. At the $28 \mathrm{~d}$ reexposure period the increase relative to acutely treated mice approached, but did not quite reach statistical significance $(p<0.07)$, whereas at the 7 and $14 \mathrm{~d}$ reexposure intervals the turnover of $\mathrm{NE}$ was at an intermediate level. In contrast to the variations of NE turnover, within the PVN neither DOPAC, DA, 5-HIAA, nor 5-HT varied among the treatment groups.

Within the locus coeruleus the accumulation of MHPG varied as a function of the treatment condition $\left(F_{(6,114)}=3.35 ; p<\right.$ $0.01)$. The multiple comparisons indicated that a single injection of TNF- $\alpha(1.0 \mu \mathrm{g})$ increased MHPG accumulation relative to saline-treated mice. Reexposure to TNF- $\alpha$ was likewise associated with an elevation of the metabolite concentration, particularly at the 1 and $28 \mathrm{~d}$ intervals. In no instance, however, was the rise greater than that observed in mice that received only a single injection of the cytokine (Fig. 4). Indeed, this conclusion was confirmed by a separate analysis of the $\mathrm{MHPG} / \mathrm{NE}$ ratio. In addition to the altered turnover, concentrations of NE within the locus coeruleus were altered by the TNF- $\alpha$ treatments $\left(F_{(6,118)}=\right.$ 3.07; $p<0.01)$. The multiple comparisons indicated that levels of $\mathrm{NE}$ were increased by acute administration of the cytokine. Likewise, after reexposure to TNF- $\alpha$ at 7 and $28 \mathrm{~d}$ after the initial treatment, the levels of NE were elevated relative to that of saline-treated animals, but a comparable rise was not evident at the $1 \mathrm{~d}$ reexposure interval. In fact, at this time NE levels were lower than among mice acutely treated with the cytokine. In effect, these data suggest that after reexposure to TNF- $\alpha 28 \mathrm{~d}$ after initial treatment the increased use of $\mathrm{NE}$ was met with a compensatory increase of synthesis, leading to elevated amine concentrations. However, at the $1 \mathrm{~d}$ reexposure interval a compensatory increase of synthesis was not provoked, hence precluding elevated concentrations of $\mathrm{NE}$.

Within the hippocampus the levels of NE and 5-HT were unaffected by treatment with TNF- $\alpha$, whereas concentrations of the metabolites MHPG and 5-HIAA were significantly influenced by the cytokine $\left(F_{(6,116)}=2.51\right.$ and $2.18 ; p<0.05$, respectively). Once again, MHPG was increased by the acute administration of TNF- $\alpha$, as well as by reexposure to the cytokine, at least at the 1 and 28 d intervals between injections. However, there was no indication of a sensitization effect, because the extent of the increase was comparable with that observed after a single administration of TNF- $\alpha$ (Table 3). Likewise, in the case of 


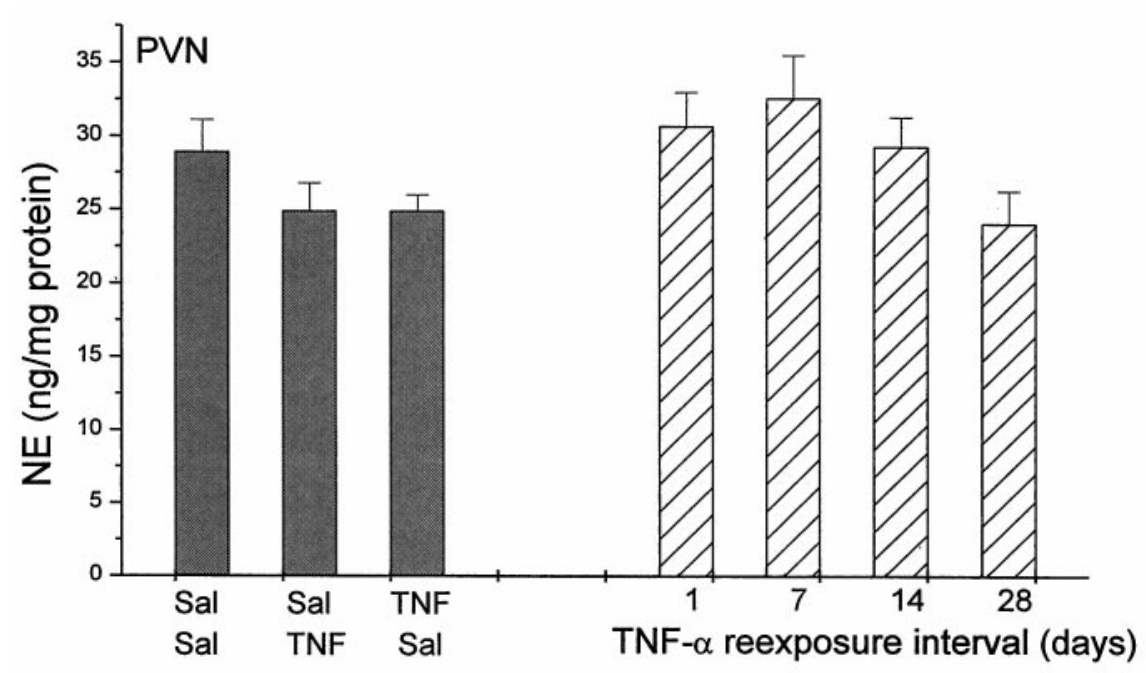

Figure 3. Mean \pm SEM concentrations of NE (top) and MHPG (bottom) within the PVN as a function of TNF- $\alpha$ treatment. The three groups on the left (solid bars) received saline on two occasions, saline followed 2 weeks later by the low dose of TNF- $\alpha(1.0$ $\mu \mathrm{g})$, or a high dose of TNF- $\alpha(4.0 \mu \mathrm{g})$ followed 2 weeks later by saline. The four groups on the right (hatched bars) received an initial $4.0 \mu \mathrm{g}$ dose of TNF- $\alpha$ followed by a second $1.0 \mu \mathrm{g}$ dose $1,7,14$, or $28 \mathrm{~d}$ later. The protein (mean \pm SEM) concentrations of the PVN equaled $7.65 \pm 0.24 \mu \mathrm{g} .{ }^{*} p<0.05$ relative to saline-treated mice.

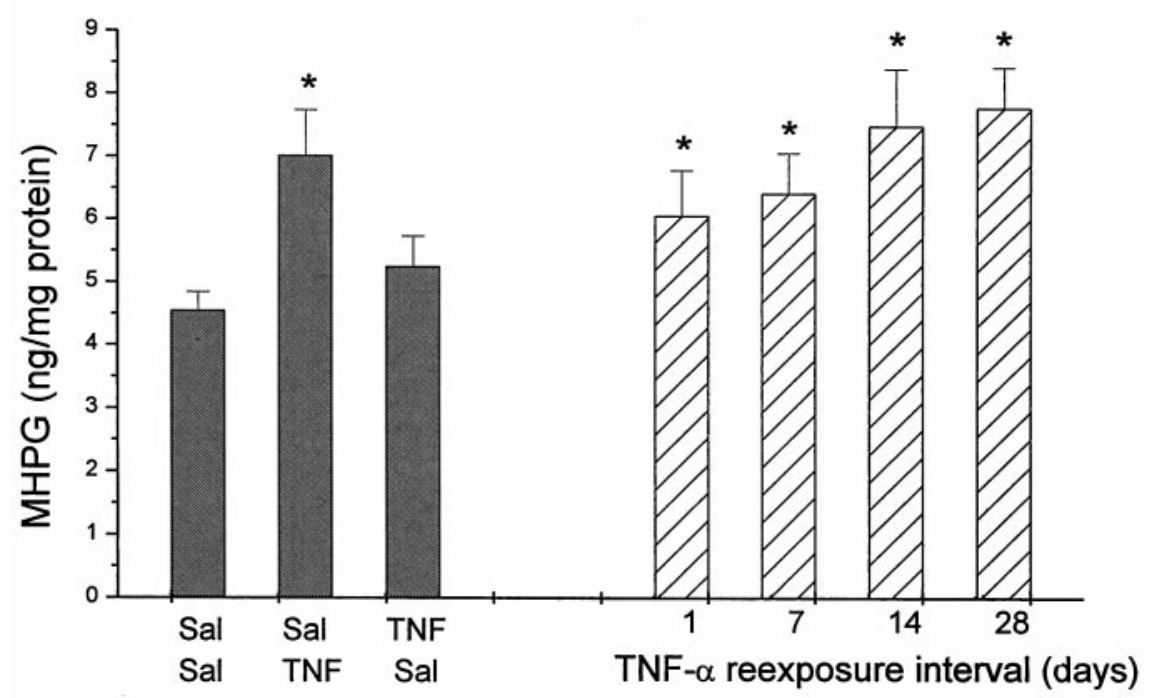

5-HIAA it was found that acute treatment as well as reexposure to TNF- $\alpha$ enhanced the metabolite accumulation; once again, however, there was no indication of a sensitization effect being apparent.

The amine variations within the PFC could be dissociated from those seen in the PVN, hippocampus, and locus coeruleus. Within the PFC, the levels of MHPG varied as a function of the TNF- $\alpha$ treatment $\left(F_{(6,127)}=10.60 ; p<0.01\right)$. The multiple comparisons confirmed that relative to saline-treated mice, $\mathrm{MHPG}$ levels were elevated after acute administration of TNF- $\alpha$. In mice that were reexposed to the cytokine $1 \mathrm{~d}$ after the initial treatment, a further elevation of MHPG accumulation was evident, such that the metabolite concentrations were double that of mice that had received the acute treatment. Interestingly, if the TNF- $\alpha$ was administered 7, 14, or $28 \mathrm{~d}$ after the initial treatment, then metabolite levels exceeded those of saline-treated mice but were comparable to those seen after acute cytokine treatment (Fig. 5). The levels of NE were likewise found to vary as a function of the cytokine administration $\left(F_{(6,127)}=3.84 ; p<0.01\right)$. Acute TNF- $\alpha$ did not affect the levels of the transmitter; however, in mice reexposed to the cytokine at the $1 \mathrm{~d}$ interval the levels of $\mathrm{NE}$ exceeded those of saline animals or those of mice that had received acute TNF- $\alpha$ treatment. At longer reexposure intervals the NE concentrations were indistinguishable from those of acutely treated mice (data not shown). Unlike NE and MHPG, the levels of DA and DOPAC were not significantly influenced by the cytokine treatments. However, it is noteworthy that, although not significantly elevated, DOPAC accumulation was increased by $65 \%$ in animals reexposed to the cytokine $1 \mathrm{~d}$ after the initial treatment, whereas at longer intervals the increase was less pronounced $(20-40 \%)$.

Although TNF- $\alpha$ administration affected 5-HT activity within the PFC, the profile apparent at the various reexposure intervals was clearly distinguishable from that observed with respect to NE activity. Specifically, although the levels of 5-HT were not affected by the cytokine, the accumulation of 5-HIAA varied significantly as a function of the treatment mice received $\left(F_{(6,126)}=5.41 ; p<0.01\right)$. The multiple comparisons confirmed that a single administration of the low dose of TNF- $\alpha$ provoked a marked elevation of 5-HIAA, whereas the $4.0 \mu \mathrm{g}$ dose administered 2 weeks earlier was without effect. If mice were reexposed to TNF- $\alpha 1 \mathrm{~d}$ after the initial treatment, then the levels of 5-HIAA were not significantly different from those of salinetreated animals and were lower than those of acutely treated mice. In contrast, with TNF- $\alpha$ reexposure 7, 14, or $28 \mathrm{~d}$ after the initial treatment, levels of 5-HIAA within the PFC were signifi- 

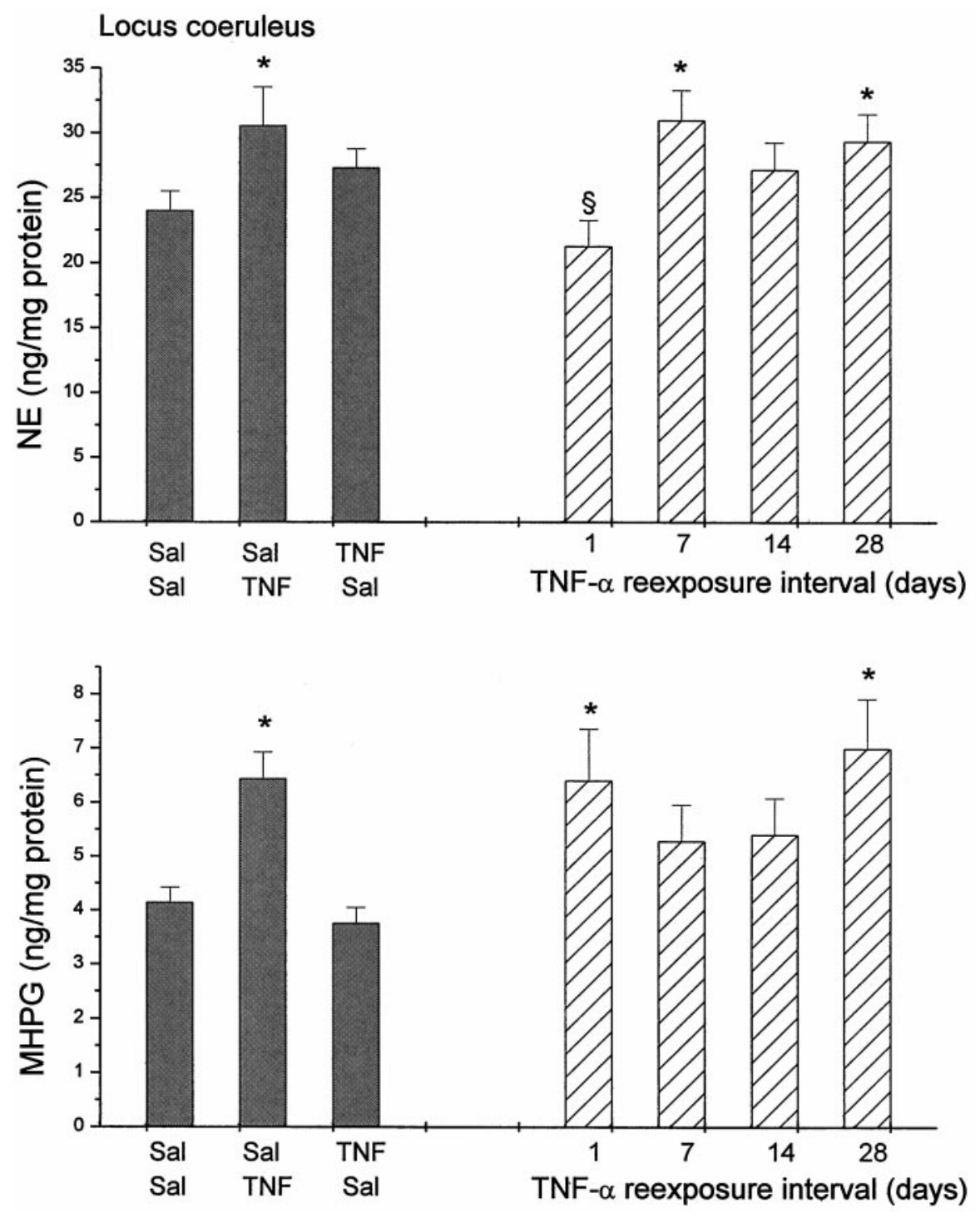

Figure 4. Mean \pm SEM concentrations of NE (top) and MHPG (bottom) within the locus coeruleus as a function of TNF- $\alpha$ treatment. The three groups on the left (solid bars) received saline on two occasions, saline followed 2 weeks later by the low dose of TNF- $\alpha(1.0 \mu \mathrm{g})$, or a high dose of TNF- $\alpha$ $(4.0 \mu \mathrm{g})$ followed 2 weeks later by saline. The four groups on the right (hatched bars) received an initial $4.0 \mu \mathrm{g}$ dose of TNF- $\alpha$ followed by a second $1.0 \mu \mathrm{g}$ dose $1,7,14$, or $28 \mathrm{~d}$ later. The protein (mean \pm SEM) concentrations of the locus coeruleus were $19.62 \pm 0.77 \mu \mathrm{g} .{ }^{*} p<0.05$ relative to saline-treated mice; ${ }^{s} p<0.05$ relative to mice that received acute TNF injection.

Table 3. Concentrations of hippocampal MHPG and 5-HIAA $($ mean \pm SEM $)$

\begin{tabular}{lll} 
& $\begin{array}{l}\text { MHPG } \\
(\mu \mathrm{g} / \mathrm{mg} \text { protein })\end{array}$ & $\begin{array}{l}\text { 5-HIAA } \\
(\mu \mathrm{g} / \mathrm{mg} \text { protein })\end{array}$ \\
\hline Sal/sal & $3.60 \pm 0.30$ & $4.40 \pm 0.56$ \\
$\mathrm{Sal} / \mathrm{TNF}$ & $4.97 \pm 0.53^{*}$ & $6.86 \pm 0.75^{*}$ \\
$\mathrm{TNF} / \mathrm{sal}$ & $4.22 \pm 0.56$ & $4.73 \pm 0.69$ \\
$\mathrm{TNF} / \mathrm{TNF}$ (1 d) & $5.11 \pm 0.55^{*}$ & $6.63 \pm 0.57^{*}$ \\
$\mathrm{TNF} / \mathrm{TNF}$ (7 d) & $4.22 \pm 0.33$ & $6.93 \pm 0.79^{*}$ \\
$\mathrm{TNF} / \mathrm{TNF}$ (14 d) & $3.63 \pm 0.41$ & $6.17 \pm 0.83^{*}$ \\
$\mathrm{TNF} / \mathrm{TNF}$ (28 d) & $5.46 \pm 0.53^{*}$ & $5.75 \pm 0.62^{*}$
\end{tabular}

Protein (mean \pm SEM) concentrations of hippocampal punches were $81.55 \pm$ $2.32 \mu \mathrm{g}$.

${ }^{*} p<0.05$ relative to saline/saline $(\mathrm{Sal} / \mathrm{sal})$-treated mice.

cantly increased relative to saline-treated mice and were comparable with those of mice that received acute TNF- $\alpha$ administration (Fig. 5). In effect, it appeared that the initial cytokine treatment provoked a desensitization in response to later TNF- $\alpha$ administration, but this effect was only apparent at the earliest retest period.

The NE variations associated with TNF- $\alpha$ within the central amygdala were, in several respects, reminiscent of the variations seen within the PFC. Specifically, although the levels of NE did not vary significantly, MHPG accumulation was markedly influenced by the treatments $\left(F_{(6,122)}=2.57 ; p<0.01\right)$. The multiple comparisons showed that acute administration of the cytokine produced a relatively modest $(40 \%)$, nonsignificant elevation of MHPG (Fig. 6). However, a much greater rise (86\%) was seen in mice that received the $1.0 \mu \mathrm{g}$ dose $1 \mathrm{~d}$ after the initial TNF- $\alpha$ treatment. In contrast, at longer reexposure intervals the metabolite accumulation was not enhanced relative to that of salinetreated mice. Thus, although TNF- $\alpha$ provoked the sensitization of amygdala $\mathrm{NE}$ activity in response to later challenge with the cytokine, this effect was again restricted to the earliest time point.

In contrast to the variations of $\mathrm{NE}$ activity, the changes of 5-HT and DA functioning within the central amygdala were markedly different from those seen within the PFC. In the case of 5-HT levels, the TNF- $\alpha$ treatment was without effect, whereas 


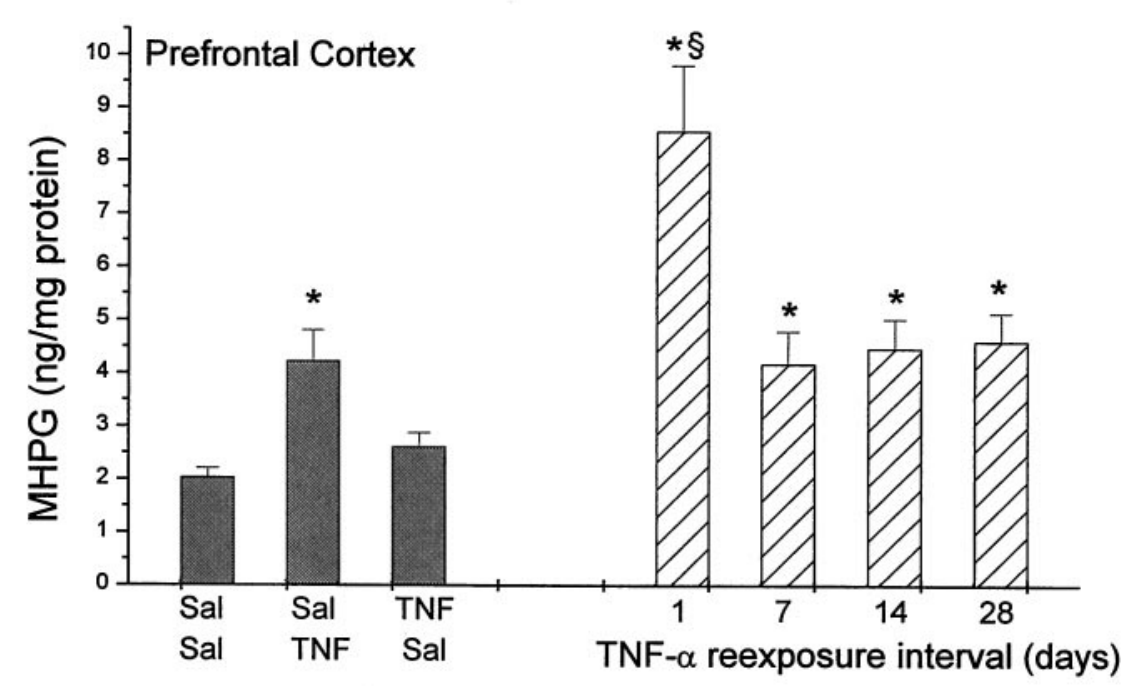

Figure 5. Mean \pm SEM concentrations of MHPG (top) and 5-HIAA (bottom) within the PFC as a function of the TNF- $\alpha$ treatment mice received. The three groups on the left (solid bars) received saline on two occasions, saline followed 2 weeks later by the low dose of TNF- $\alpha(1.0 \mu \mathrm{g})$, or a high dose of TNF- $\alpha(4.0 \mu \mathrm{g})$ followed 2 weeks later by saline. The four groups on the right (hatched bars) received an initial $4.0 \mu \mathrm{g}$ dose of TNF- $\alpha$ followed by a second $1.0 \mu \mathrm{g}$ dose $1,7,14$, or $28 \mathrm{~d}$ later. The protein (mean \pm SEM) concentration of the PFC equaled $286.70 \pm 8.72 \mu \mathrm{g}$. ${ }^{*} p<0.05$ relative to saline-treated mice; ${ }^{\circledR} p<0.05$ relative to mice that received acute TNF- $\alpha$ injection.

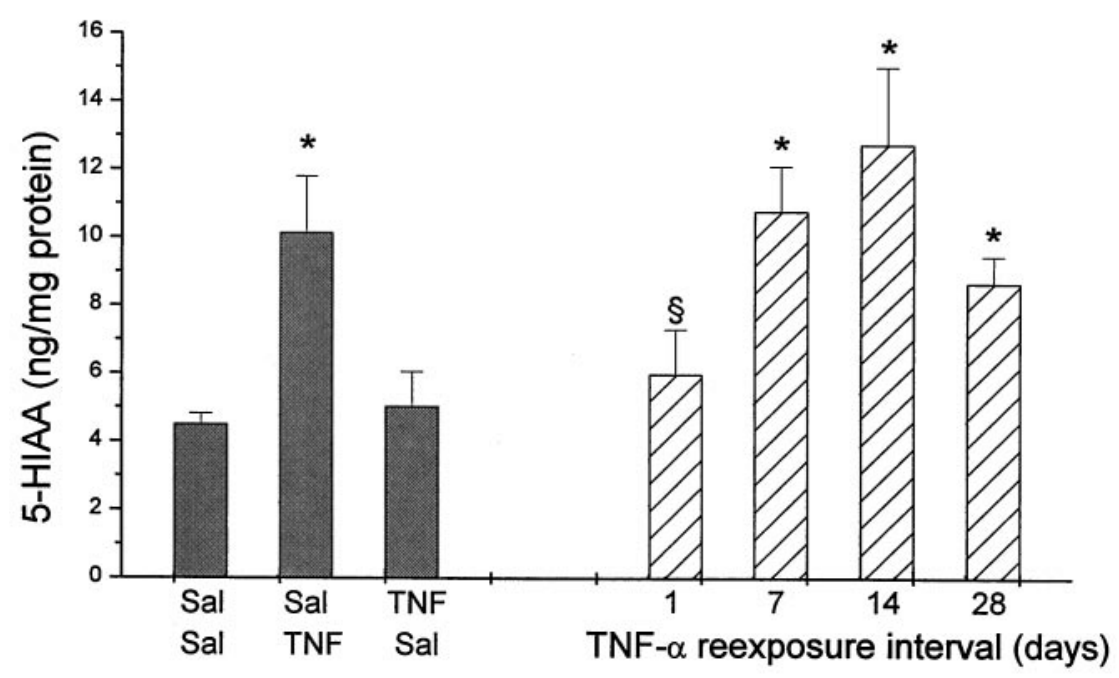

5-HIAA accumulation was appreciably influenced by the cytokine $\left(F_{(6,122)}=3.46 ; p<0.01\right)$. Among mice that were acutely treated with TNF- $\alpha$ or mice that received the cytokine 2 weeks earlier, the accumulation of 5-HIAA was somewhat elevated, but in neither case was the increase a statistically significant one. However, as seen in Figure 6, among mice that received the cytokine on two occasions, the accumulation of 5-HIAA was relatively marked at each of the reexposure intervals, with the greatest accumulation being evident at the $7 \mathrm{~d}$ period.

Finally, DA levels within the central amygdala were unaffected by the TNF- $\alpha$ treatment, although there appeared to be somewhat of an elevation, particularly at the 14 and $28 \mathrm{~d}$ reexposure periods. The accumulation of DOPAC, however, varied significantly as a function of the cytokine treatments $\left(F_{(6,121)}=2.40\right.$; $p=0.03)$. The multiple comparisons indicated that acute TNF- $\alpha$ did not significantly affect DOPAC accumulation, being associated with only a $20 \%$ rise of the metabolite. However, in mice that were reexposed to the cytokine the levels of DOPAC were reduced relative to acutely treated mice (data not shown). This effect was particularly pronounced at the longer reexposure intervals, and at the $14 \mathrm{~d}$ interval DOPAC accumulation was significantly lower than that seen in saline-treated animals.

\section{Behavioral effects of murine TNF- $\alpha$}

Inasmuch as the preceding experiments involved human TNF- $\alpha$ (hTNF- $\alpha$ ), the possibility was considered that the outcomes observed reflected cross-species TNF- $\alpha$ effects (e.g., timedependent endotoxic reaction to hTNF- $\alpha$ ). Accordingly, an additional experiment was conducted to evaluate the effects of acute murine TNF- $\alpha$ on sickness behaviors, as well as the effects of reexposure to this cytokine. Murine TNF- $\alpha$ was obtained from $\mathrm{R}$ $\&$ D Systems and had a specific activity of $2.7 \times 10^{5} \mathrm{U} / \mu \mathrm{g}$. Mice of five groups ( $n=10$ per group) received two intraperitoneal injections $28 \mathrm{~d}$ apart; treatment comprised either two saline injections, administration of saline followed $28 \mathrm{~d}$ later by murine TNF- $\alpha$ (mTNF- $\alpha ; 1.0 \mu \mathrm{g}$ ), or mTNF- $\alpha$ (at doses of $0.5,1.0$, or 2.0 $\mu \mathrm{g}$ ) followed $28 \mathrm{~d}$ later by the $1.0 \mu \mathrm{g}$ dose of the cytokine. Sickness behaviors (overall appearance, locomotion, and social interaction) were determined and analyzed as described earlier.

The ANOVA confirmed that the mTNF- $\alpha$ treatment markedly affected the overall appearance of the mice $\left(F_{(4,45)}=8.42 ; p<\right.$ 0.01 ; locomotor activity, $F_{(4,45)}=5.68 ; p<0.01$; and social interaction, $\left.F_{(4,45)}=7.72 ; p<0.01\right)$. As seen in Table 4 and confirmed by Newman-Keuls multiple comparisons, the acute 

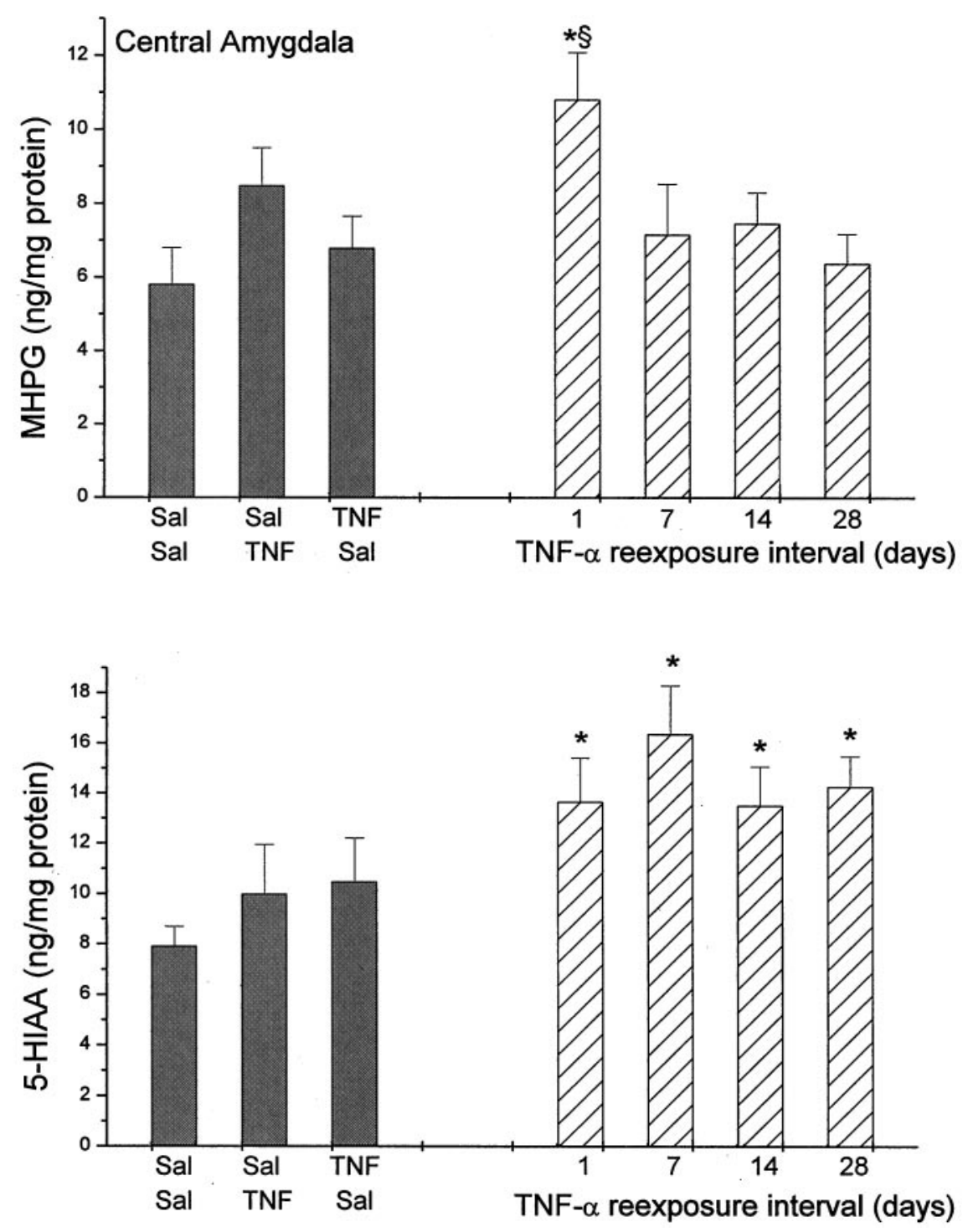

Figure 6. Mean \pm SEM concentrations of MHPG (top) and 5-HIAA (bottom) within the central amygdala as a function of the TNF- $\alpha$ treatment. The three groups on the left (solid bars) received intraperitoneal administration of saline on two occasions, saline followed 2 weeks later by the low dose of TNF- $\alpha(1.0$ $\mu \mathrm{g})$, or a high dose of TNF- $\alpha(4.0 \mu \mathrm{g})$ followed 2 weeks later by saline. The four groups on the right (hatched bars) received an initial $4.0 \mu \mathrm{g}$ dose of TNF- $\alpha$ followed by a second $1.0 \mu \mathrm{g}$ dose $1,7,14$, or $28 \mathrm{~d}$ later. The protein (mean $\pm \mathrm{SEM}$ ) concentrations of the central amygdala were $21.90 \pm 0.51 .{ }^{*} p<0.05$ relative to saline treated-mice; ${ }^{\S} p<0.05$ relative to mice that received acute TNF- $\alpha$ injection.

administration of $\mathrm{mTNF}-\alpha$ hardly influenced behavior relative to saline-treated mice. However, this dosage of the cytokine markedly influenced sickness behaviors among mice that had previously received $\mathrm{mTNF}-\alpha$. This was the case regardless of the dosage mice previously received (i.e., even when mice had initially received subthreshold doses of the cytokine). In each instance, the reexposure treatment elicited marked illness profiles relative not only to saline treated animals but also to those that had received acute mTNF- $\alpha$ administration. As well, the extent of the illness became progressively more pronounced over the course of the $1 \mathrm{hr}$ evaluation session. In fact, by the end of the session $\sim 50 \%$ of the animals reexposed to mTNF- $\alpha$ appeared moribund, whereas only 1 of 10 mice that received acute mTNF- $\alpha$ exhibited obvious illness.

\section{DISCUSSION}

\section{Behavioral effects of TNF- $\alpha$}

Commensurate with earlier reports (Bluthe et al., 1994; Kent et al., 1996), TNF- $\alpha$ dose-dependently elicited sickness behaviors, which were subject to a time-dependent sensitization, as observed with other pharmacological and stressor treatments (Antelman, 1988). Reexposure to the cytokine either 1 or $7 \mathrm{~d}$ after initial treatment provoked few signs of sickness. However, at longer reexposure intervals palatable food consumption was greatly reduced, and mice displayed ptosis, ruffled fur, curled body posture, immobility, and reduced social exploration. This effect was not exclusive to mice that received human TNF- $\alpha$, because a behavioral sensitization was also elicited by the recombinant murine form of the cytokine.

\section{Effects of hTNF- $\alpha$ on plasma corticosterone}

Elevated HPA functioning can be elicited by lipopolysaccharide (LPS) (Rivier, 1993; Ericsson et al., 1994), systemic IL-1 $\beta$ (Dunn, 1988, 1990; Zalcman et al., 1994; Van Der Meer et al., 1996), and TNF- $\alpha$ (Bernardini et al., 1990). Conversely, central administration of antibodies directed against $\mathrm{TNF}-\alpha$ reduced the ACTH response to LPS (Turnbull and Rivier, 1998). Coupled with the finding that TNF- $\alpha$ elicits an anxiogenic effect (Connor et al., 1998), the increased plasma corticosterone supports the contention that TNF- $\alpha$ is interpreted centrally as if it were a stressor. This is not to say that processive (psychological) and systemic (metabolic) stressors involve identical mechanisms. The HPA alterations elicited by processive stressors may involve activation of limbic forebrain regions, whereas systemic stressors (e.g., cy- 
Table 4. Behavioral scores as a function of initial or reexposure (28 d later) to mTNF- $\alpha$

\begin{tabular}{llll} 
& Sickness profile & Motor activity & Social interaction \\
\hline Sal/sal & $1.0 \pm 0$ & $2.60 \pm 0.13$ & $1.82 \pm 0.06$ \\
Sal/TNF $(1.0 \mu \mathrm{g})$ & $1.6 \pm 0.11$ & $2.02 \pm 0.15^{*}$ & $1.78 \pm 0.11$ \\
$\mathrm{TNF}(0.5 \mu \mathrm{g}) / \mathrm{TNF}(1.0 \mu \mathrm{g})$ & $3.0 \pm 0.20^{*, * *}$ & $1.35 \pm 0.12^{*, * *}$ & $2.98 \pm 0.18^{*, * *}$ \\
$\mathrm{TNF}(1.0 \mu \mathrm{g}) / \mathrm{TNF}(1.0 \mu \mathrm{g})$ & $2.8 \pm 0.20^{*, * *}$ & $1.60 \pm 0.14^{*, * *}$ & $2.98 \pm 0.17^{*, * *}$ \\
$\mathrm{TNF}(2.0 \mu \mathrm{g}) / \mathrm{TNF}(1.0 \mu \mathrm{g})$ & $2.8 \pm 0.18^{*, * *}$ & $1.30 \pm 0.11^{*, * *}$ & $2.95 \pm 0.18^{*, * *}$
\end{tabular}

$* p<0.05$ relative to saline/saline $(\mathrm{Sal} / \mathrm{sal})$.

$* * p<0.05$ relative to Sal/TNF.

tokines) stimulate brainstem nuclei, which directly innervate the PVN (Herman and Cullinan, 1997).

Paralleling the behavioral changes, corticosterone alterations associated with TNF- $\alpha$ reexposure varied over time since the initial treatment. After reexposure to the cytokine after $28 \mathrm{~d}$, plasma corticosterone levels exceeded those of acutely treated mice but were reduced at a $1 \mathrm{~d}$ reexposure interval. In effect, the cytokine may have either a sensitizing or desensitizing effect, depending on the time of its readministration. Although the p55 receptor may play a primary role in subserving the actions of TNF- $\alpha$ in mice (Benigni et al., 1996; Sipe et al., 1996), the p75 receptor may also contribute in this respect (Ericcson et al., 1994; Declercq et al., 1998). However, it appears unlikely that the time-dependent sensitization was related to alterations of receptor sensitivities, because murine TNF- $\alpha$, which stimulates both receptor subtypes, also promoted a time-dependent sensitization of sickness and corticosterone levels (Hayley et al., 1999). The finding that TNF- $\alpha$ biphasically influences the response to later cytokine treatment is consistent with reports of critical periods during which TNF- $\alpha$ pretreatment has either sensitizing or desensitizing effects (Wallach et al., 1988; Matsuura and Galanos, 1990). The source for such time-dependent actions is unclear but may reflect interactions involving other endogenous cytokines, including interferon- $\gamma(\mathrm{IFN}-\gamma)$ and IL-12 (Cauwels et al., 1995, 1996), IFN- $\gamma$ and TNF- $\alpha$ (Bundschuh et al., 1997; Nansen et al., 1997), and IFN- $\gamma$ and IL-1 $\beta$ (Chung and Benveniste, 1990). An alternative explanation for the sensitization comes from studies that showed that viruses may sensitize neurons to some of the cytotoxic effects of TNF- $\alpha$ by inhibiting the production of an as yet unidentified, endogenous protective factor, thereby increasing susceptibility to subsequent challenges (Sipe et al., 1996).

In the context of potential central mechanisms mediating cytokine- and stressor-elicited sensitization, an exciting mechanistic model was offered involving the synthesis of hypothalamic regulatory peptides (Tilders et al., 1993; Schmidt et al., 1995, 1996; Tilders and Schmidt, 1998). It was demonstrated that with the passage of time after IL- $1 \beta$ administration or stressor exposure a phenotypic change occurred within CRH terminals of the median eminence, such that AVP coexpression was increased. Thus, the augmented pituitary ACTH secretion elicited by subsequent IL- $1 \beta$ or stressor challenge may reflect the synergistic actions of these secretagogues (Bartanusz et al., 1993; Tilders et al., 1993; Schmidt et al., 1996). Inasmuch as TNF- $\alpha$ stimulates $\mathrm{CRH}$ and ACTH activity, it remains possible that this cytokine, like IL-1 $\beta$, engenders upregulation of AVP expression, hence promoting a time-dependent sensitization. In the case of the IL- $1 \beta$ effects, the phenotypic AVP and CRH coexpression was relatively long-lasting and influenced the response to later cytokine or stressor challenges (Schmidt et al., 1995; Tilders and Schmidt, 1998). Although some sensitization effects observed in the present investigation were clearly transient, notably the extrahypothalamic amine variations, other effects, including the corticoid and NE alterations in the PVN, were clearly longlasting. Whether these effects were permanent or were modifiable by other treatments remains to be determined.

\section{Central neurotransmitter variations}

Within 1 hr of its systemic administration, marked central neurochemical alterations were induced by TNF- $\alpha$. It is not clear whether these actions were mediated directly (i.e., penetration into the brain via passive or active transport) (Gutierrez et al., 1993) or indirectly, through stimulation of afferent neural circuits (e.g., vagal and/or spinal projections) (Dantzer et al., 1998; Maier and Watkins, 1998) or enzymatic alterations at peripheral target sites, such as the liver (Libert et al., 1991). Receptors for IL-1 $\beta$ have been demonstrated on the nodose vagal ganglia, which sends projections to several brain regions, notably the nucleus of the solitary tract (Ek et al., 1998). As well, LPS and IL-1 $\beta$ induce c-fos expression in this vagal complex (Gaykema et al., 1998; Goehler et al., 1998). Interestingly, as in the case of IL-1 $\beta$, subdiaphragmatic vagotomy abrogated the effects of peripheral administration of TNF- $\alpha$ on conditioned taste aversion, fever, and circulating corticosterone levels (Goehler et al., 1995; Fleshner et al., 1998; Maier and Watkins, 1998), suggesting that TNF- $\alpha$ also influences central processes by stimulating vagal afferents. Regardless of the mechanism, it is apparent that acute TNF- $\alpha$ administration increased the accumulation of the NE metabolite MHPG within the PVN. Because monoamines stimulate $\mathrm{CRH}$ release from the median eminence (Fuller, 1992; Pacak et al., 1992, 1995; Dinan, 1996), it is possible that corticosterone elevations induced by TNF- $\alpha$ were secondary to the amine alterations. In addition to the hypothalamic amine variations, TNF- $\alpha$ also influenced amine activity at several extrahypothalamic sites. Commensurate with in vitro observations (Ignatowski et al., 1997), acute TNF- $\alpha$ increased NE use within the locus coeruleus and the dorsal hippocampus and enhanced 5-HT activity in the PFC and hippocampus. Yet, in vivo dialysis studies indicated that central TNF- $\alpha$ administration did not affect hippocampal 5-HT release (Pauli et al., 1998), raising the possibility that tissue level changes do not necessarily translate into alterations of amine release.

The central circuitry associated with cytokine treatment may involve several pathways and sites of entry into brain, culminating in diffuse neuronal activation (Brady et al., 1994; Rivest, 1995). Interestingly, after cytokine challenge, c-fos mRNA expression 
may follow a biphasic temporal course across brain regions (Rivest, 1995), likely reflecting different diffusion routes or actions of the cytokines (Brady et al., 1994; Gaillard, 1995). Inasmuch as amine activity in the present investigation was only determined at a single time ( $1 \mathrm{hr})$ after TNF- $\alpha$ treatment, the fine temporal resolution possible using in vivo dialysis could not be discerned (Westerink, 1995), and it is possible that biphasic, region-specific amine variations were associated with the treatment.

As observed with respect to CRH and AVP after IL- $1 \beta$ challenge (Schmidt et al., 1995, 1996; Tilders and Schmidt, 1998), time-dependent sensitization of central monoamine activity was associated with TNF- $\alpha$ administration. However, several distinct temporal patterns of regional monoamine activity were apparent after TNF- $\alpha$ reexposure. In particular, the profile of NE use within the PVN (reflected by MHPG accumulation and the $\mathrm{MHPG} / \mathrm{NE}$ ratio) paralleled the time-dependent corticosterone changes, being greater with reexposure $28 \mathrm{~d}$ after initial treatment than at the $1 \mathrm{~d}$ interval. In contrast, within the PFC and central amygdala, increased $\mathrm{NE}$ use was evident with reexposure to TNF- $\alpha 1 \mathrm{~d}$ after the initial treatment but entirely absent at longer intervals. The early sensitization of amine activity coincided with the desensitization of plasma corticosterone seen after reexposure to TNF- $\alpha$. Because the PFC may exert inhibitory control over neuroendocrine actions of the PVN (Herman and Cullinan, 1997), it is possible that the sensitization of PFC amine activity may involve such an inhibitory neural circuit.

The mechanisms responsible for the region- and timedependent sensitization patterns is not immediately evident. However, functionally, it might be expected that cytokine treatments, by virtue of their effects on central neurotransmitter functioning, may affect behavioral outputs. Although the progressive rise of PVN NE activity may be related to illness symptoms, the early sensitization (i.e., the enhanced PFC and amygdala amine increases), appeared independent of illness factors, because mice did not display obvious malaise at this time. However, it is possible that other effects engendered by TNF- $\alpha$ (e.g., vigilance, arousal, and anxiety) (Connor et al., 1998) may be related to the aminergic alterations. In this respect, consideration of the time-dependent central actions of TNF- $\alpha$ and IL- $1 \beta$ may be relevant, particularly given their potential therapeutic use.

Finally, one further issue warrants some consideration. Specifically, a mild ischemic episode or electrical stimulation of the brain causing seizure (kindling) may protect against the damaging consequences elicited by a later, more pronounced insult (Glazier et al., 1994; Kelly and McIntyre, 1994; Barone et al., 1998). Such effects may, among other things, be dependent on the timing of the two incidents (Barone et al., 1998). Although cytokines may underlie these neuroprotective effects (Tasaki et al., 1997; Nawashiro et al., 1997), cytokines could also act in a neurodestructive manner (Buttini et al., 1994; Saito et al., 1996; Rothwell et al., 1997). Although several factors could account for cytokines acting in both manners (e.g., cytokine dosage and cofactors released from glial cells), it might be considered that time-dependent sensitization or desensitzation associated with challenges may contribute to the specific actions provoked.

\section{REFERENCES}

Anisman H, Merali Z (1999) Cytokines and stress in relation to anxiety and anhedonia. In: Cytokines, stress and depression (Dantzer R, Wollmann EE, Yirmiya R, eds). London: Plenum, in press.

Antelman SM (1988) Time-dependent sensitization as the cornerstone for a new approach to pharmacotherapy: drugs as foreign/stressful stimuli. Drug Dev Res 14:1-30.

Barone FC, White RF, Spera TA, Ellison J, Currie RW, Wang X, Feuerstein GZ (1998) Ischemic preconditioning and brain tolerance: temporal histological and functional outcomes, protein synthesis requirement, and interleukin-1 receptor antagonist and early gene expression. Stroke 29:1937-1951.

Bartanusz V, Jezova D, Bertini LT, Tilders FJ, Aubry JM, Kiss JZ (1993) Stress-induced increase in vasopressin and corticotropin-releasing factor expression in hypophysiotrophic paraventricular neurons. Endocrinology 132:895-902.

Benigni F, Faggioni R, Sironi M, Fantuzzi G, Vandenabeele P, Takahashi N, Sacco S, Fiers W, Buurman WA, Ghezzi P (1996) TNF receptor p55 plays a major role in centrally mediated increases of serum IL-6 and corticosterone after intracerebroventricular injection of TNF. J Immunol 157:5563-5568.

Bernardini R, Kamilaris TC, Calogero AE, Johnson EO, Gomez MT, Gold PW, Chrousos GP (1990) Interactions between tumor necrosis factor- $\alpha$, hypothalamic corticotropin-releasing hormone, and adrenocorticotropin secretion in the rat. Endocrinology 126:2876-2881.

Blalock JE (1994) The syntax of immune-neuroendocrine communication. Immunol Today 15:504-511.

Bluthe RM, Pawlowski M, Suarez S, Parnet P, Pittman Q, Kelley KW, Dantzer R (1994) Synergy between tumor necrosis factor- $\alpha$ and interleukin-1 in the induction of sickness behavior in mice. Psychoneuroendocrinology 19:197-207.

Bluthe RM, Michaud B, Kelley KW, Dantzer R (1996) Vagotomy attenuates behavioral effects of interleukin-1 injected peripherally but not centrally. NeuroReport 7:1485-1488.

Brady LS, Lynn AB, Herkenham M, Gottesfeld Z (1994) Systemic interleukin-1 induces early and late patterns of c-fos mRNA expression in brain. J Neurosci 14:4951-4964.

Brebner K, Hayley S, Merali Z, Anisman H (1998) Synergistic actions of interleukin- $1 \beta$, interleukin- 6 and TNF- $\alpha$ : central neurochemical, neuroendocrine and behavioral alterations. Soc Neurosci Abstr 24:2075.

Bundschuh DS, Barsig J, Hartung T, Randow F, Docke W-D, Volk H-D, Wendel A (1997) Granulocyte-macrophage colony-stimulating factor and IFN- $\gamma$ restore the systemic TNF $\alpha$ response to endotoxin in lipopolysaccharide-desensitized mice. J Immunol 158:2862-2871.

Buttini M, Sauter A, Boddeke HW (1994) Induction of interleukin-1 beta mRNA after focal cerebral ischemia in the rat. Mol Brain Res 23:126-134.

Cauwels A, Brouckaert P, Grooten J, Huang S, Aguet M, Fiers W (1995) Involvement if IFN- $\gamma$ in Bacillus Calmette-Guerin-induced but not in tumor-induced sensitization to TNF-induced lethality. J Immunol 154:2753-2763.

Cauwels A, Fiers W, Brouckaert P (1996) Murine IL-12 is involved in Calmette Guerin Bacillus-induced sensitization and is by itself sufficient to sensitize mice to the lethal effects of human TNF. J Immunol 156:4686-4690.

Chiueh CC, Zukowska-Grojec Z, Kirk KL, Kopin IJ (1983) 6-Fluorocatecholamines as false adrenergic neurotransmitters. J Pharmacol Exp Ther 225:529-533.

Chung IY, Benveniste EN (1990) Tumor necrosis factor-alpha production by astrocytes. Induction by lipopolysaccharide, IFN-gamma and IL-1 beta. J Immunol 144:2999-3007.

Connor TJ, Song C, Leonard BE, Merali Z, Anisman H (1998) An assessment of the effects of central interleukin-1 $\beta,-2,-6$ and tumor necrosis factor- $\alpha$ administration on some behavioural, neurochemical, endocrine and immune parameters in the rat. Neuroscience 84:923-933.

Dantzer R, Bluthe RM, Laye S, Bret-Dibat JL, Parnet P, Kelley KW (1998) Cytokines and sickness behavior. Ann NY Acad Sci 840:586-590.

Declercq W, Denecker G, Fiers W, Vandenabeele P (1998) Cooperation of both TNF receptors in inducing apoptosis: involvement of the TNF receptor-associated factor binding domain of the TNF receptor 75 . J Immunol 161:390-399.

Dinan TG (1996) Serotonin and the regulation of hypothalamicpituitary-adrenal axis function. Life Sci 58:1683-1694.

Dunn AJ (1988) Systemic interleukin-1 administration stimulates hypothalamic norepinephrine metabolism paralleling the increased plasma corticosterone. Life Sci 43:429-435.

Dunn AJ (1990) Interleukin-1 as a stimulator of hormone secretion. Prog Neuroendocrinimmunol 3:26-34. 
Dunn AJ (1992) The role of interleukin-1 and tumor necrosis factor alpha in the neurochemical and neuroendocrine responses to endotoxin. Brain Res Bull 6:807-812.

Dunn AJ, Welch J (1991) Stress- and endotoxin-induced increases in brain tryptophan and serotonin metabolism depend on sympathetic nervous system activity. J Neurochem 57:1615-1622.

Dunn AJ, Powell ML, Meitin C, Small PA (1989) Virus infection as a stressor: influenza virus elevates plasma concentrations of corticosterone, and brain concentrations of MHPG and tryptophan. Physiol Behav 45:591-594.

Ek M, Kurosawa M, Lundenberg T, Ericsson A (1998) Activation of vagal afferents after intravenous injection of interleukin-1 $\beta$ : role of endogenous prostaglandins. J Neurosci 18:9471-9479.

Ericsson A, Kovacs KJ, Sawchenko PE (1994) A functional anatomical analysis of central pathways subserving the effects of interleukin-1 on stress-related neuroendocrine neurons. J Neurosci 14:897-913.

Fleshner M, Goehler LE, Schwartz BA, McGorry M, Martin D, Maier SF, Watkins LR (1998) Thermogenic and corticosterone responses to intravenous cytokines (IL-1-beta and TNF-alpha) are attenuated by subdiaphramatic vagotomy. J Neuroimmunol 86:134-141.

Franklin KBJ, Paxinos G (1997) A stereotaxic atlas of the mouse brain. New York: Academic.

Fuller RW (1992) The involvement of serotonin in regulation of the pituitary-adrenocortical function. Front Neuroendocrinol 13:250-270.

Gaillard RC (1995) Immunoendocrine interactions at the hypothalamohypophyseal level. Ann Endocrinol 56:561-56.

Gaykema RP, Goehler LE, Tilders FJ, Bol JG, McGorry M, Fleshner M, Maier SF, Watkins LR (1998) Bacterial endotoxin induces fos immunoreactivity in primary afferent neurons of the vagus nerve. Neuroimmunomodulation 5:234-240.

Giulian D, Robertson C (1990) Inhibition of mononuclear phagocytes reduces ischemic injury in the spinal cord. Ann Neurol 1:33-42.

Glazier SS, O'Rourke DM, Graham DI, Welsh FA (1994) Induction of ischemic tolerance following brief focal ischemia in the rat brain. J Cereb Blood Flow Metab 14:545-553.

Goehler LE, Busch CR, Tartaglia N, Relton J, Sisk D, Maier SF, Watkins LR (1995) Blockade of cytokine induced conditioned taste aversion by subdiaphragmatic vagotomy: further evidence for vagal mediation of immune-brain communication. Neurosci Lett 185:163-166.

Goehler LE, Gaykema RPA, Hammack SE, Maier SF, Watkins LR (1998) Interleukin-1 induces c-Fos immunoreactivity in primary afferent neurons of the vagus nerve. Brain Res 804:306-310.

Gutierrez EG, Banks WA, Kastin AJ (1993) Murine tumor necrosis factor alpha is transported from blood to brain in the mouse. J Neuroimmunol 47:169-176.

Hayley S, Brebner K, Staines WA, Merali Z, Anisman H (1999) Timedependent sensitization effects associated with tumor necrosis factor- $\alpha$ : behavioral and neurochemical processes. Neuroimmunomodulation 6:224.

Herman JP, Cullinan WE (1997) Neurocircuitry of stress: central control of hypothalamo-pituitary-adrenocortical axis. Trends Neurosci 20:78-84.

Hopkins SJ, Rothwell NJ (1995) Cytokines and the nervous system. 1: Expression and recognition. Trends Neurosci 18:83-88.

Ignatowski TA, Noble BK, Wright JR, Gorfien JL, Heffner RR, Spengler RN (1997) Neuronal-associated tumor necrosis factor (TNF- $\alpha$ ): its role in noradrenergic functioning and modification of its expression following antidepressant drug administration. J Neuroimmunol 79:84-90.

Kelly ME, McIntyre DC (1994) Hippocampal kindling protects several structures from the neuronal damage resulting from kainic acid-induced status epilepticus. Brain Res 634:245-256.

Kent S, Bret-Dibat JL, Kelley KW, Dantzer R (1996) Mechanisms of sickness-induced decreases in food-motivated behavior. Neurosci Biobehav Rev 20:1171-1175.

Lacosta S, Merali Z, Anisman H (1998) Influence of Interleukin-1 on exploratory behavior, plasma ACTH, corticosterone, and central biogenic amines in mice. Psychopharmacology 137:351-361.

Libert C, Van Bladel S, Brouckaert P, Shaw A, Fiers W (1991) Involvement of the liver, but not of IL-6, in IL-1 induced desensitization to the lethal effects of tumor necrosis factor. J Immunol 146:2625-2632.

Linthorst ACE, Flachskamm C, Muller-Preuss P, Holsboer F, Reul JMHM (1995) Effect of bacterial endotoxin and interleukin-1 $\beta$ on hippocampal serotonergic neurotransmission, behavioral activity, and free corticosterone levels: an in vivo microdialysis study. J Neurosci 15:2920-2934.

Maier SF, Watkins LR (1998) Cytokines for psychologists: implications of bidirectional immune-to-brain communication for understanding behavior, mood, and cognition. Psychol Rev 105:83-107.

Matsuura M, Galanos C (1990) Induction of hypersensitivity to endotoxin and tumor necrosis factor by sublethal infection with Salmonella typhimurium. Infect Immun 58:935-937.

Merali Z, Lacosta S, Anisman H (1997) Effects of interleukin-1 $\beta$ and mild stress on alterations of norepinephrine, dopamine and serotonin neurotransmission: a regional microdialysis study. Brain Res 761:225-235.

Nansen A, Christensen JP, Marker O, Thomsen AR (1997) Sensitization to lipopolysaccharide in mice with asymptomatic viral infection: role of T cell-dependent production of interferon-gamma. J Infect Dis 176:151-157.

Nawashiro H, Tasaki K, Ruetzler CA, Hallenbeck JM (1997) TNFalpha pretreatment induces protective effects against cerebral focal ischemia in mice. J Cereb Blood Flow Metab 17:483-490.

Pacak K, Armando I, Fukuhara K, Kvetnansky R, Palkovits M, Kopin IJ, Goldstein DS (1992) Noradrenergic activation in the paraventricular nucleus during acute and chronic immobilization stress in rats: an in vivo microdialysis study. Brain Res 589:91-96.

Pacak K, Palkovits M, Kopin IJ, Goldstein DS (1995) Stress-induced norepinephrine release in the hypothalamic paraventricular nucleus and pituitary-adrenocortical and sympathoadrenal activity: in vivo microdialysis studies. Front Neuroendocrinol 16:89-150.

Pauli S, Linthorst ACE, Reul JMHM (1998) Tumor necrosis factor- $\alpha$ and interleukin-2 differentially affect hippocampal serotonergic neurotransmission, behavioral activity, body temperature and hypothalamicpituitary-adrenocortical axis activity in the rat. Eur J Neurosci 10:868-878.

Ravindran AV, Merali Z, Anisman H (1997) Dysthymia: a biological perspective. In: Dysthymia: from clinical neuroscience to treatment (Licinio J, Bolis CL, Gold P, eds), pp 21-44. Geneva: World Health Organization.

Rivest S (1995) Molecular mechanisms and neural pathways mediating the influence of interleukin- 1 on the activity of neuroendocrine CRF motoneurons in the rat. Int J Dev Neurosci 13:135-146.

Rivier C (1993) Effect of peripheral and central cytokines on the hypothalamic-pituitary-adrenal axis of the rat. Ann NY Acad Sci. 697:97-105.

Rothwell NJ, Allan S, Toulmond S (1997) The role of interleukin-1 in acute neurodegeneration and stroke: pathophysiological and therapeutic implications. J Clin Invest 100:2648-2652.

Saito K, Suyama K, Nishida K, Sei Y, Basile AS (1996) Early increase of TNF- $\alpha$, IL- 6 and IL- $1 \beta$ levels following transient cerebral ischemia in gerbil brain. Neurosci Lett 206:149-152.

Sato S, Reiner SL, Jensen MA, Roos RP (1997) Central nervous system mRNA expression following Theilers murine encephalomyelitis virus infection. J Neuroimmunol 76:213-223.

Schmidt ED, Janszen AWJW, Wouterlood FG, Tilders FJH (1995) Interleukin-1 induced long-lasting changes in hypothalamic corticotropin-releasing hormone ( $\mathrm{CRH})$ neurons and hyperresponsiveness of the hypothalamus-pituitary-adrenal axis. J Neurosci 15:7417-7426.

Schmidt ED, Binnekade R, Janszen AW, Tilders FJH (1996) Short stressor induced long-lasting increases of vasopressin stores in hypothalamic corticotropin-releasing hormone $(\mathrm{CRH})$ neurons in adult rat. J Neuroendocrinol 8:703-712.

Seegal RF, Brosch KO, Bush B (1986) High-performance liquid chromatography of biogenic amines and metabolites in brain, cerebrospinal fluid, urine and plasma. J Chromatogr 377:131-144.

Shanks N, Zalcman S, Zacharko RM, Anisman H (1991) Alterations of central norepinephrine, dopamine and serotonin in several strains of mice following acute stressor exposure. Pharmacol Biochem Behav 38:69-75.

Sipe KJ, Srisawasdi D, Dantzer R, Kelley KW, Weyhenmeyer JA (1996) An endogenous $55 \mathrm{kDa}$ TNF receptor mediates cell death in a neural cell line. Mol Brain Res 38:222-232.

Song C, Merali Z, Anisman H (1999) Variations of nucleus accumbens dopamine and serotonin following systemic interleukin-1, interleukin-2 or interleukin-6 treatment. Neuroscience 88:823-836.

Tasaki K, Reutzler C, Ohtsuki T, Martin D, Nawashiro H, Hallenbeck JM 
(1997) Lipopolysaccharide pretreatment induces resistance against subsequent focal cerebral ischemic damage in spontaneously hypertensive rats. Brain Res 748:267-270.

Tilders FJH, Schmidt ED (1998) Interleukin-1-induced plasticity of hypothalamic $\mathrm{CRH}$ neurons and long-term stress hyperresponsiveness. Ann NY Acad Sci 840:65-73.

Tilders FJH, Schmidt ED, de Goeij DCE (1993) Phenotypic plasticity of CRF neurons during stress. Ann NY Acad Sci 697:39-52.

Turnbull AV, Rivier CL (1998) Intracerebroventricular passive immunization. I. The effect of intracerebroventricular administration of an antiserum to tumor necrosis factor- $\alpha$ on the plasma adrenocorticotropin response to lipopolysaccharide in rats. Endocrinology 139: $119-127$.
Van Der Meer MJ, Sweep CG, Pesman GJ, Tilders FJH, Hermus AR (1996) Chronic stimulation of the hypothalamus-pituitary-adrenal axis in rats by interleukin-1 $\beta$ : central and peripheral mechanisms. Cytokine 12:910-919.

Wallach D, Holtmann H, Engelmann H, Nophar Y (1988) Sensitization and desensitization to lethal effects of tumor necrosis factor and IL-1. J Immunol 140:2994-2999.

Westerink BHC (1995) Brain microdialysis and its application for the study of animal behaviour. Behav Brain Res 70:103-124.

Zalcman S, Green-Johnson JM, Murray L, Nance DM, Dyck D, Anisman H, Greenberg A (1994) Cytokine-specific central monoamine alterations induced by interleukin (IL)-1, IL-2 and IL-6. Brain Res 643:40-49. 